Egyptian Journal of Aquatic Biology \& Fisheries

Zoology Department, Faculty of Science,

Ain Shams University, Cairo, Egypt.

ISSN $1110-6131$

Vol. 23(2): 275 - 290 (2019)

www.ejabf.journals.ekb.eg

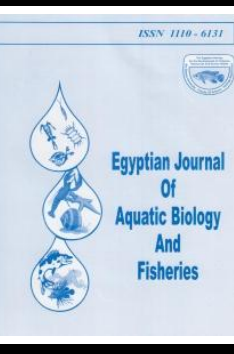

\title{
Molecular and Histological Studies of Salinity effect on gills and liver of Coptodon zillii in Egypt
}

\author{
Amira I. Nofal ${ }^{1 *}$, Nahla H. El-Shaer ${ }^{2}$ and Amany E. Nofal ${ }^{3}$ \\ 1- Genetic Engineering Lab, National Institute of Oceanography and Fisheries, Egypt. \\ 2- Dept. of Zoology, Faculty of Science, Zagazig University, Egypt. \\ 3- Dept. of Zoology, Faculty of Sciences, Menoufia University, Egypt. \\ * Corresponding author: anofal@ list.ru
}

\section{ARTICLE INFO \\ Article History: \\ Received: March 26, 2019 \\ Accepted: April 25, 2019 \\ Online: May 2019}

\section{Keywords:}

Coptodon zillii

Salinity

Gills

Liver

Caspase-3

Prolactin

\begin{abstract}
The good growth performance of tilapia species has been recorded in nearly isosmotic salinities. The present study aimed to evaluate the effect of salinity on the structure of Coptodon zillii, being one of the most salinity tolerant tilapia species. Qaroun Lake looses water by evaporation which affects the water levels of the lake and its salinity, recently was subjected to a sharp rise in salinity degrees, which led to a sharp decrease in the rate of fish production. Histological, histochemical, immunohistochemical and genetic studies are used as accurate tests for evaluating the effects of salinity in Tilapia fish. The results showed that fish obtained from Wadi El Rayan1 showed semi typical structure of gill and liver, others from Wadi El Rayan2 showed slight deviations from normal one, on the contrary, samples from Qaroun lake exhibited a series of severe variations; histological changes as severe degeneration, necrosis, edema, hemorrhage, and Hemosidrin, as well as, a reduction in the distribution of carbohydrates, an increase of collagen amount and a strong caspase- 3 expression in gill and liver cells. Moreover, the genetic results indicated a clear sensitivity of prolactin gene to different degrees of salinities, which can possibly control the euryhalinity capacity of $C$. zillii. All of these results demonstrated the strong effect of the high elevation of salinity on fish production and the histological structure of the internal tissues of one of the most important fish in Egypt.
\end{abstract}

\section{INTRODUCTION}

Qaroun Lake is considered one of the most important ancient natural lakes in Egypt; it is the third largest lake in Egypt which can be considered as a natural reservoir in fayoum depression with annual production of about 3000 tones (EISerafy, 2014). In the past, it received agricultural water from her surrounding lands resulting in salinity balance and refreshing of lake water, but this has led to a high level of groundwater, threatening the agricultural land in the region. In order to solve this problem, it was decided to implement a project to discharge a large part of this water to El-Rayan lowlands. Qaroun lake from 2016 has been closed and became non-renewable leading to an increase level of water salinity, plankton, and pollution rate, which are respectively leading to high death rate of different fish species and stop of fishing in the lake most time of the year (Abd Ellah, 2016; 12-Wadi El-Rayan Protected Area in Fayoum Governorate, 2018). 
Payne (1986) reported that Lake Qaroun will be converted to a salt pan as a result of high level of evaporation due to high temperature degree.

Tilapias are popular cultured species due to their high environmental tolerances, their good growth rate and early maturation; all of this makes them desirable species for brackish water farming. Consequently, for many years, tropical aquaculturists have tried to develop saline tilapia culture. Unfortunately, the saline water tilapias $(C$. zillii) have poor-growing performance. $C$. zillii widely has been found in the Middle East and has been introduced outside its native range. It is one of the most important food fish and sometimes used as ornamental fish in aquarium fish trade (Froes, et al., 2016). Mageed (1998) recorded that salinity of Wadi EL-Rayan $1 \& 2$ and Lake Qaroun is increasing with time and this has a bad effect on the quality and quantity of zooplankton, with strong recommendation that this increasing salinity should be managed.

EL-Naggar et al. (2009) reported that different water conditions were affected on the structure and morphology of fish at different sites. The digestive system and gills were suffered from morphological and histological changes as a result of their direct contact with water with different environmental changes (Yuan et al., 2010). Many studies were carried out to indicate the response of different type of tilapia to different salinity levels to recognize the best condition for their culture as the level of salinity has a great role for studying the evolutionary history of different types of fish (Riche and Williams, 2010).

There is a close relationship between the physiological state of the organism and the environmental conditions surrounding it. Hormones of the neuroendocrine system play a fundamental role in the organization of osmoregulatory mechanisms. Prolactin $(P R L)$ is a hormone that played an important role for freshwater adaptation (Sakamoto and McCormick, 2006), is known as the saline water-adapting hormone in most euryhaline teleosts, having a major role in regulating water and ion permeability of the pituitary gland (Ariel $\boldsymbol{e t}$ al., 2015) and involved in a variety of functions in growth, development, osmoregulation, and reproduction (Mancera and McCormick, 2007).

\section{MATERIALS AND METHODS}

\section{Sampling Sites}

15 fish samples of $C$. zillii were collected at August 2018 from three stations in Fayoum Governorate in Egypt; Qaroun, upper and lower lakes of Wadi El Rayan (WR1 and WR2, respectively), five samples from each Lake. The highest lake salinity is in Qaroun (55-62 ppt). Wadi El-Rayan has been used for man-made lakes from agricultural drainage which has made a reserve of the two separate Wadi El Rayan Lakes. The reserve is composed of an upper lake (WR1) and a lower lake (WR2), with waterfalls between the two lakes. Wadi El Rayan is a natural environment clean, quiet, beautiful and pollution-free lake. WR1 salinity ratio is about $1.5 \mathrm{~g} / \mathrm{L}(1-2 \mathrm{ppt})$ and its water is semi-saline and renewable. WR2 salinity is higher than the WR1 and is about $2.5 \mathrm{~g} / \mathrm{L}(4-12 \mathrm{ppt})$ as a result of the evaporation process. The maintenance of animals and experimental procedures were approved by the animal ethical committee in accordance with the guide for care and use of laboratory animals (Approval No. MUFS / F / HI / 1 / 19)

\section{Water sampling and analysis}

In August 2018, 15 water samples were collected regularly from the three lakes under this study, five samples from each lake, the samples were collected in one 
season with the aim of controlling the external factors affecting the fish so that the effect that was determined was due to the change in the degrees of salinity mainly without the interference of any other environmental effect such as temperature. The summer was chosen because it is the most active season in the rate of growth in fish. Water analysis such as Salinity (S), temperature $(\mathrm{T})$ and $\mathrm{pH}$ value were measured directly in sampling sites with salinometer, thermometer, and $\mathrm{pH}$ meter (Model; TDS3/ Temperture (TEMP)/ PPM,TDS Meter, Tester Rang : 0-9990 ppm), Part Per Million (PPM) and Total Dissolved Solids (TDS) are the salinity units of the salinometer.

\section{Statistical analysis}

The present data were analyzed by using one-way analysis of variance (ANOVA) test. All values were expressed as mean \pm standard deviation (Mean \pm $\mathrm{SD}$ ). Differences were regarded as significant if probability value $\mathrm{p}<0.05$ and highly significant if $\mathrm{p}<0.001$.

\section{Sections preparation}

Samples of gill and liver of the C. zillii were collected from WR1, WR2, and Qaroun lakes. Immediately after fish dissection, gill and liver were quickly and carefully fixed in $10 \%$ neutral formalin for 24 hours, washed overnight in running tap water, and then rinsed in distal water. The fixed organs were dehydrated in gradual series of ethanol (70\% - 100\%), placed in 2 changes of xylene, and then embedded in paraplast paraffin $\left(56-58{ }^{0} \mathrm{C}\right)$. The paraffin sections were cut (about $5 \mu \mathrm{m})$ using rotary microtome and then were put on clean slides on digital hot plate at $40^{\circ} \mathrm{C}$ for sections spreading and water evaporation. Routine histology study was done on paraffin sections stained by Haematoxylene and eosin (H\&E) staining method (Suvarna et al., 2018).

\section{Histochemical Study}

Special stains were applied for chemical localization of carbohydrate and collagen in the gill and liver. Paraffin sections were treated with Periodic acid Schiff's (PAS) reaction (Adams, 1965) for demonstration of polysaccharides and mucosubstances, as well as, Masson's Trichrome (TRI) (Bancrof and Stevens,1982) for demonstration of collagen.

\section{Immunohistochemical Study}

Cysteine-aspartic proteases (caspase-3) is an indicator for the occurrence of apoptosis, Immunohistochemical variations were observed by using suitable antibodies of anti-caspase stain (Hsu et.al., 1981).

The percentages of the positive staining areas were quantified by using Image-Pro plus software.

\section{Genetic preparation}

The level of prolactin hormone can be affected and varies according to the physiological condition of the fish such as the nutrition available and its quantity as well as the state of reproduction, on the other hand, the measurement of PRL mRNA for prolactin which is the gene responsible primarily for the adaptation of fish to salinity in the surrounding environment is strong indicator and scale to determine the relationship between salinity and proactin hormone. For examination of the developmental changes in the prolactin receptor mRNA, samples of $C$. zilli were collected from different salinity degree's from three lakes; WR1, WR2, and Qaroun. Pituitary glands were extracted and preserved in later solution (Thermo fisher/ Cat. No. AM7021) and stored at $-80^{\circ} \mathrm{C}$. 


\section{RNA extraction}

Total RNA was extracted from the preserved tissues by the acidguanidiumphenol-chloroform method (Chomczynski and Sacchi, 1987). The quantity of the total RNA samples was determined via spectrophotometry (Thermo scientific, 1088) at $260 \mathrm{~nm}$.

\section{cDNA synthesis}

The total RNA samples were reverse-transcribed with SuperScript II RNase Hreverse transcriptase (Invitrogen) and oligo-dT primers to obtain first-strand cDNA.

\section{Quantitative real-time PCR}

Tilapia cDNA regions of $\beta$-actin (BA) as the control was amplified by PCR using primers as follows: for BA, 5'-CTACGAGC-TGCCTGACGGACA-3' and 5'CACATGTGC TGGAAGGTGGACA-3'. For prolactin receptor (PRLR), the sequences of primers are as follows:5-CAGAGATCAAATGCCGTTCTCC-3, forward 5-ATTTCAGGCAG CCGTCA TGATC-3, reverse (Yada et al., 2002). The first-strand cDNAs were diluted 1:20 in TE buffer and used as templates for the reverse transcription quantitative PCR (RT-qPCR) analysis. PCR was performed for 35 cycles (denaturation at $95^{\circ} \mathrm{C}$ for $30 \mathrm{sec}$, annealing at $59^{\circ} \mathrm{C}$ for $1 \mathrm{~min}$, and extension at $72^{\circ} \mathrm{C}$ for $1 \mathrm{~min}$ ) and $0.25 \mu \mathrm{m}$ of each primers.

\section{RESULTS}

Different extracts of T. ornata, C. myrica and P. pavonica were tested for their antimicrobial activity against three strains of microorganisms by disc diffusion method. However, the results of antimicrobial activity against tested pathogens are presented in Table (1) and Figures (2-4).

Table 1: The concenteration and the purity of $p r l$ mRNA in pituitary gland of C. zillii.

\begin{tabular}{ccc} 
Sample ID & Concentration/260 & Purity/280 \\
\hline \multicolumn{3}{|c}{ Wadi El-Rayan (1) Lake } \\
$\mathbf{2}$ & 330 & 1.85 \\
$\mathbf{3}$ & 256 & 2.00 \\
$\mathbf{4}$ & 270 & 1.97 \\
& 305 & 1.94 \\
$\mathbf{5}$ & Wadi El-Rayan (2) Lake & \\
$\mathbf{6}$ & 290 & 1.80 \\
$\mathbf{7}$ & 243 & 1.86 \\
$\mathbf{8}$ & 339 & 2.00 \\
& 190 & 1.96 \\
$\mathbf{9}$ & Qaroun Lake & \\
$\mathbf{1 0}$ & 315 & 2.05 \\
$\mathbf{1 1}$ & 266 & 2.00 \\
$\mathbf{1 2}$ & 258 & 1.94 \\
\end{tabular}

This work confirmed that, salinity of WR2 has been presented brackish water which is higher than fresh water in WR1, whereas Qaroun Lake has been characterized by the higher salinity level reached to 62 PPT presenting hypersalinity water (Fig. $1_{\mathrm{a}}$ ). Temperature at the three lakes was a round $25^{\circ} \mathrm{C}$ because all samples were collected in the same week of August 2018 (summer season) (Fig. $1_{\mathrm{b}}$ ). pH at Qaroun lake degraded from 7.5 to 8.8 while at WR1 from 8.1 to 8.9 and WR2 from 8.5 to 9.04 as shown in Figure $\left(1_{\mathrm{c}}\right)$. 


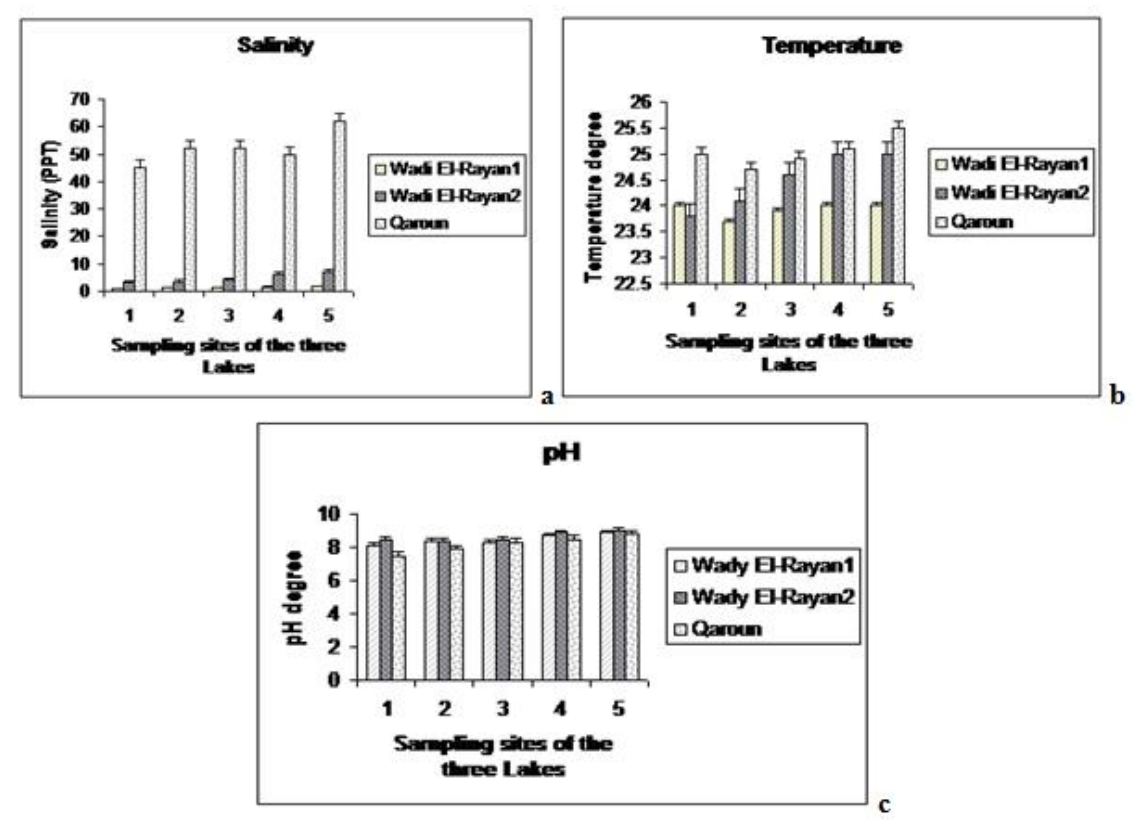

Fig. 1: Diagrams of (a) Salinity, (b) Temperature, (c) pH degrees in the three Lakes.

\section{Histological alterations of gill}

Microscopic examination of gill sections obtained from WR1 showed semi typical histological structure; gills consist of four cartilaginous arches on each side of the buccal cavity. Each one of these arches is composed of several primary filaments with two rows of secondary lamellae. The filament between the lamellae is lined by a thick stratified epithelial layer. WR1 gills also showed slight alterations; lamellar epithelium lifting, vasodilation with vascular congestion (Fig. 2a). Similar, gills obtained from WR2 showed slight deviations, such as, vasodilatation of lamellar axis, lifting of the lamellar epithelium and edema (Fig. $2_{b}$ ). However, a series of severe changes were noted in samples from Qaroun lake; including lamellar deformations as characterized by hypotrophy, evident epithelium interstitial edema with dilated primary filament, an intense lamellar epithelium lifting, fusion of the adjacent secondary lamellae in numerous areas as a result of filament epithelium proliferation, cytoplasmic vacuolation, necrosis and changes in the distribution of mucus cells (Fig. 2 c).

\section{Histological alterations of Liver}

Liver samples collected from WR1 showed a normal hepatic structure. Liver consists of a homogenous cytoplasm hepatocyte with a large central or a central spherical nucleus and a densely stained nucleolus. Hepatocytes were not oriented into distinct lobules but were arranged in branched laminae and separated by blood sinusoids. They were located among sinusoids forming cord like structure around tributaries of the hepatic vein known as hepatic cell cords. The pancreatic area was observed, which is corresponds to the acini of exocrine pancreas. Gills collected from WR1 also showed slight abnormalities; hemorrhage in pancreatic area and congestion in blood sinusoid (Fig. $3_{\mathrm{a}}$ ). Tilapia collected from WR2 exhibited some histological variation in liver structure; mild degeneration in hepatic cells, congestion in blood sinusoid and hemorrhage in both hepatic and pancreatic area (Fig. $3_{\mathrm{b}}$ ). The environmental conditions in Qaroun Lake affected strongly on the liver structure, such as severe degeneration in hepatic and pancreatic area, lower eosinophilia of 
liver cells, necrosis and edema, hemorrhage in hepatic tissue, and Hemosidrin iron pigment accumulation (Fig. $3_{\mathrm{c}}$ ).

\section{Histochemical observations}

After reaction with Periodic acid Schiff's, large amounts of glycogen granules were observed in the cytoplasm and basement membrane of different type of cells of both gill and liver of healthy $C$. zillii which appeared as a large number of different sizes reddish or magenta granules with PAS-negative stained nuclei indicating absolute lack of glycogen. Examination of sections obtained from gill and liver of Qaroun lake fish exhibited more diminution in their carbohydrates contents than those from Wadi El Rayan lakes (Figs. 4\&5).

Masson's Trichrome Stain was used to differentiate between collagen and smooth muscle in gill and liver (Figs. 6\&7). Examination of gill and liver sections of samples from Qaroun lake exhibited more expression of collagen than those from Wadi El Rayan lakes.

\section{Immunohistochemical observations}

Immunohistochemical examination showed nearly negative caspase-3 expression in fish obtained from WR1. Caspase-3 is one of the main indicators of cell apoptosis. Samples obtained from WR2 showed weak caspase-3 expression appeared as brownish color in the cytoplasm. On the other hand, samples from Qaroun lake exhibited a strong caspase-3 expression in the cytoplasm of gill and liver cells (apoptotic cells) (Figs. 8\&9).

\section{Genetic results}

The concentration and the purity of $p r l$ mRNA in pituitary gland of $C$. zillii were shown in Table (1). The expression of $P R L$ mRNA was quantified simultaneously using a newly developed real time PCR assay. Calculation of RNA concentration was carried out using the formula $\mathrm{R}=2-\left(\mathrm{C}_{\mathrm{T}}\right.$ sample $\left.-\mathrm{C}_{\mathrm{T}} \mathrm{HKG}\right)-\left(\mathrm{C}_{\mathrm{T}}\right.$ caliber $(+$ control $)-\mathrm{C}_{\mathrm{T}} \mathrm{HKG}$ (+control). Figure 10 showed the effect of environmental salinity on the ratio of $P R L$ mRNA relative to b-Actin (actb) mRNA in the pituitary gland of C. zilli.; the expression of PRL. in fish reared in fresh water (Wadi El-Rayan1) was significantly stimulated more than that in saline water adapted fish, with the maximum levels at the lowest salinity (1ppt) and the minimum values in the highest salinity (62ppt).
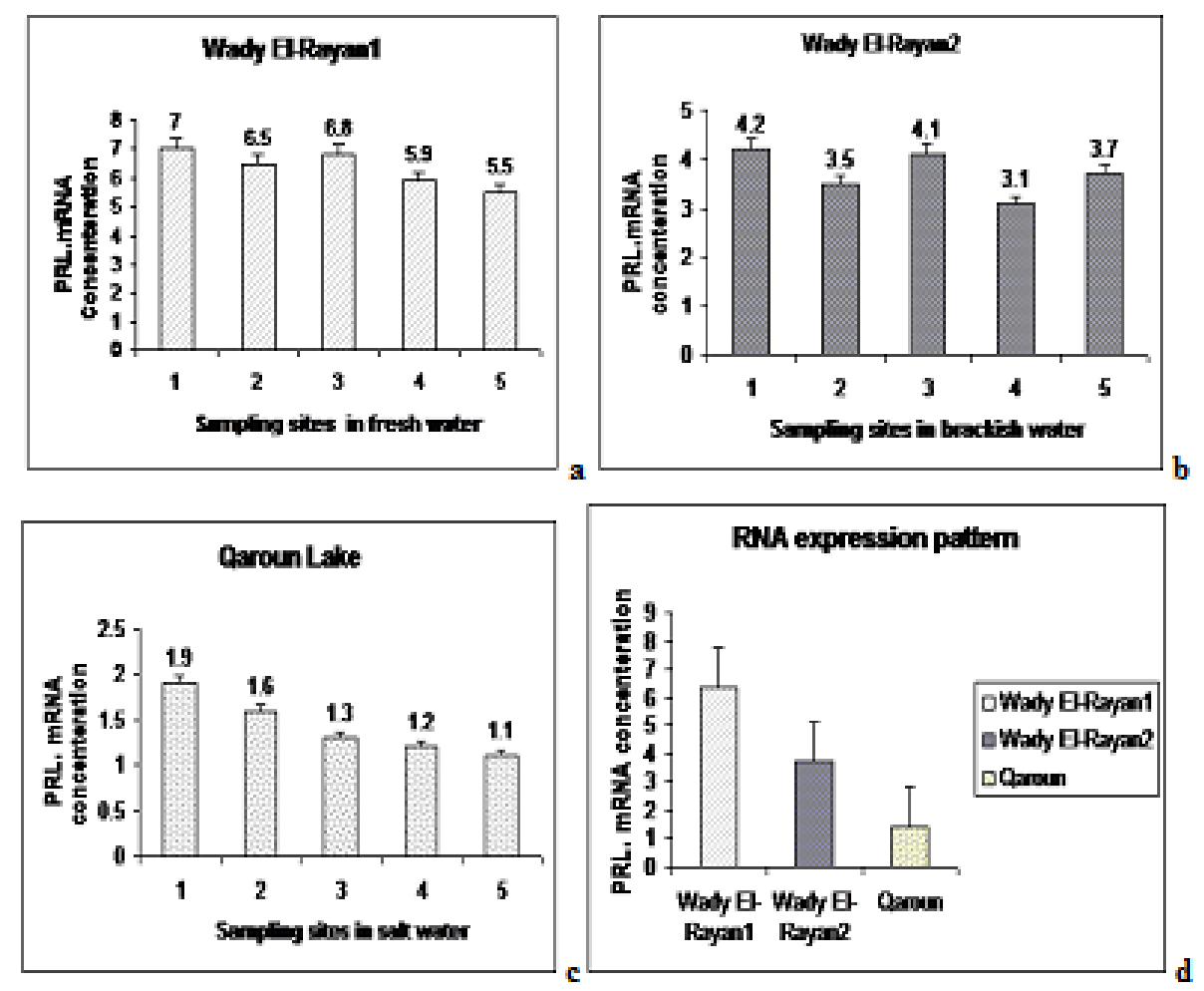

Fig. 10: prl mRNA expression patterns in pituitary gland of $C$. zillii from the three lakes. 


\section{DISCUSSION}

This study was conducted on samples collected from the field which is the three lakes. This study contributes to the recording of the hydrological survey of the lakes which are important water bodies in Egypt in terms of changes in salinity, temperature and acidity. The study also contributes to determining the effect of salinity in tilapia, which is a preferred type of food and a common source of protein in Egypt and one of the most important fish species in the world fish production.

Different environmental conditions such as; salinity, temperature, and $\mathrm{pH}$ were affected on growth, development, the histological and morphological structure of aquatic organisms. The histological observations are usually used as a test for estimating cytotoxic effects of water pollutants in fish and establishing water quality criteria (EL-Naggar et al., 2009).

Gills and liver are important critical organs for the fish, responsible for respiration and digestion. In the present work, histological alterations of gill and liver were more observed in fish obtained from Qaroun lake, which became nonrenewable and exposed to highest salinity, heavy metals concentrations and pollution, leading to the deterioration of the histological structure of the organs, leading to a general reduction of the health status of fish and thus increase the mortality rate and severe decrease of fish production from this lake. The histological examinations of gill and liver showed several histopathlogical changes; cell degeneration, necrotic area, hemorrhage, lower eosinophilia, edema and leucocytic infilteration as indicators to the occurrence of cell injure and inflammation. These results are in agreement with that obtained by some investigators. Different types of pollutants and heavy metals were affected on the histological structure of spleen, liver, kidney and muscle of fish depending on its concentration, time of exposure, and other's environmental conditions (Barbara and Malgorzata, 2006; Ayas et al., 2007; EL-Naggar et al., 2011). Large surface area of fish gills is in direct and continuous contact with the external environment; so they are significantly affected by chemical and physical changes in its aquatic environment (Yoon et al., 2015; Neuraste et al., 2017) ).

Histopathological changes and cytotoxicity of gill induced by the continuous entry of the toxicants from water was resulted in respiratory function disturbance and electrolyte imbalance by reducing its surface area (Cerqueira and Fernandes, 2002). Azevedo et al. (2015) mentioned that, Oreochromis gills were exhibited several histopathological abnormalities and high mortality rate as a result of different salinity degree.

Mallatt (1985) revealed that, the interstitial edema in gill epithelium induced by exposed to different types of heavy metals. The observation of both edema and lifting of lamellar epithelium serve as a mechanism of self-defense (Arellano et al., 1999). Paris-Palacios et al. (2000) demonstrated that, the changes in number, size and shape of the nucleus of liver cells have often been regarding as a result of high metabolic activity due to exposed to contaminants. Cell proliferation and increased thickness of gill filament epithelium are happened after exposed to heavy metal or pollutants (Van Heerden et al., 2004; Figueiredo-Fernandes et al., 2007).

Histochemical observations in the current study revealed a decrease in carbohydrate contents and an increase in the collagen and mucous in gill and liver of samples obtained from Qaroun Lake. Similarly, changes in the number and distribution of mucus cells in the gills indicated cell injure as healthy fish continuously secreted and replaced its mucus layer as a biological barrier to protect 
themselves from infectious microorganisms (Salinas et al., 2011). Pollutants and heavy metals were caused many histopathological alterations on different organs by inducing oxidative stress and intensive lesion to mucus tissues in both animals and human (Authman et al., 2012, Sharma et al., 2014). Increased levels of caspase-3 expression in most of the cells of gill and liver of samples obtained from Qaroun lake were observed in the present study. The caspase-3 protein is an immune-marker of apoptosis, which is one of the cysteine-aspartic acid protease family (Chrysomali et al., 2003). The histochemical, immunohistochemical results were correspond exactly with the histological one.

In the present study, levels of PRLR mRNA relative to BA mRNA (PRLR/BA) in pituitary gland of $C$. zilli were significantly higher in fish kept in fresh water (FW) than in those in saline water (SW). This is consistent with the change in PRLR mRNA in the pituitary gland following transfer of Nile tilapia to blackish water (20\%), as measured by Northern-blot analysis (Sandra et al., 1995, Yamaguchi $e t$ al., 2018). The expression of PRLR mRNA in the pituitary gland seems to be upregulated by the higher levels of circulating PRLs present in FW than in SW or in blackish water (Ayson et al., 1993; Auperin et al., 1994).

Ayson et al. (1994) reported significantly higher expression of PRL 188 mRNA in the pituitary of tilapia (O.mossambicus) larva reared in FW than those in SW at the time of hatching, and in PRL 177 mRNA 2 days after hatching. In the present study, levels of PRLR mRNA were also higher in the pituitary gland of $C$. zilli in FW, as compared with those in SW. These results clearly indicate the presence of regulatory mechanisms of the hormone production in the pituitary. According to Auperin et al. (1995), specific binding of PRLs to the gill membrane of Nile tilapia was significantly higher in the fish kept in blackish water than in FW. This suggests that the receptor protein is down-regulated at high concentrations of circulating PRLs in FW.

Woo et al. (1997) observed that, Tilapia grow in higher rate in brackish water than those grow in fresh water. Many species of tilapia especially $C$. zillii are euryhaline characterized with the capacity to tolerate variable range of salinity, as a result of being developed from a marine teleost ancestry (Suresh and Lin, 1992). Also, Yada et al. (1992) reported the decreasing of plasma PRL concentrations, after transferring of various salmonid species freshwater to seawater. Pituitary PRL mRNA concentrations decreased after transferring to saline water until the fish were transferred again to freshwater, suggested the involvement of PRL in adaptation of catfish to freshwater (Tang et al., 2001).

\section{CONCLUSION}

Environment has always paid a heavy price for human mistakes, after being one of the most important sources of fish production in Egypt, Qaroun Lake has been exposed to some dangerous environmental changes such as being closed water with preventing any sources of fresh water to enter Qaroun lake resulting in increasing salinity, plankton and pollution levels in lake, all of these environmental changes lead to increase death rate between different fish species in Qaroun lake and we loss one of most important source of fish production in Egypt. With the problem identified as high salinity and with a clear correlation between high salinity and deterioration of the histological condition of the fish is supposed to indicate that clearly the warning solution to the problem of Qaroun Lake to save the remainder of the fish wealth. Although Coptodon zillii can survive in high degrees of salinity, its 
growth rate is best in brackish water and therefore we recommend solving the problem of salinity in Qaroun Lake.

\section{Our suggestion to resolve this problem}

Qaroun Lake is faced with difficult problem, mainly high increase of its salinity with time and the need for lowering its water level by permit external sources of fresh water to the Lake like the drainage water of the agricultural lands of El Fayoum governorate through two main drains (EI Wadi and Bats). This is must be under control to reach to balance because if the volume of drainage water exceeds evaporation level, the water level of the lake will rise and may flood the neighboring cultivated and inhabited areas since the capacity of the lake is limited.

\section{REFERENCES}

Abd Ellah, R. (2016). Bathymetric study of Wadi El-Rayan Lakes, Egypt lakes. reservoirs and ponds, 10(2): 110-125.

Adams, C. (1965). Histochemistry of lipids. In: Neurohistochemistry. Adams, C. W. M. Ed, Elsevier, Amsterdam, London and New York. Chapter2: 6-66.

Arellano, J.M.; Storch V. and Sarasquete, C. (1999). Histological changes and copper accumulation in liver and gills of the Senegales Sole, Solea senegalensis. Ecotoxicol. Environment Safety, 44: 62-72.

Ariel, V.; Gideon, H.; Micha, R.; Tatiana, S.; Andrey, S. and Avner, C. (2015). Association between polymorphism in the Prolactin I promoter and growth of tilapia in saline-water. Aquaculture Reports, 1: 5-9.

Auperin, B.; Rentier-Delrue, F.; Martial, J. and Prunet, P. (1994). Evidence that two tilapia (Oreochromis niloticus) prolactins have different osmoregulatory functions during adaptation to a hyperosmotic environment. Gen Comp Endocrinol, 12: 1324.

Auperin, B.; Rentier-Delrue, F.; Martial, J. and Prunet, P. (1995). Regulation of gill prolactin receptors in tilapia (Oreochromis niloticus) after a change in salinity or hypo-physectomy. J Endocrinol., 145: 213-220.

Authman, M.M.; Abbas, W. and Gaafar, A. (2012). Metals concentrations in Nile tilapia Oreochromis niloticus from illegal fish farm in Al-Minufiya Province, Egypt and their effects on some tissues structures. Ecotoxicol. Environment Safety, 84:163-172.

Ayas, Z.; Ekmekci, G.; Ozmen, M. and Yarli, S.V. (2007). Histopathological changes in the livers and kidneys of fish in Sariyar Reservoir, Turkey. Environment Toxicology \& Pharmacology, 23: 242-249.

Ayson, F.; Kaneko, T.; Hasegawa, S. and Hirano, T. (1994). Differential expression of two prolactin and growth hormone genes during early development of tilapia (Oreochromis mossambicus) in fresh water and seawater: implications for possible involvement in osmoregulation during early life stages. Gen Comp Endocrinol., 95:143-152.

Ayson, F.; Kaneko, T.; Tagawa, M.; Hasegawa, S.; Grau, E.; Nishioka, R.; King, D.; Bern, H. and Hirano, T. (1993). Effects of acclimation to hypertonic environment on plasma and pituitary levels of two prolactins and growth hormone in two species of tilapia, Oreochromis mossambicus and Oreochromis niloticus. Gen Comp Endocrinol. 89: 138-148.

Azevedo, R.; dos Santos-Costa, K.; Figueiredo de Olivreira, K.; Flores-Lopes, F.; Arruda Teixeira-Lanna, E. and Gustavo Tavares-Braga, L. (2015). Responses of Nile tilapia to different levels of water salinity. Latin American Journal of Aquatic Research, 43(5): 828-835. 
Bancroft, J. and Stevens, A. (1982). Theory and Practice of Histological Techniques, $2^{\text {nd }}$ Ed, Churchill-Livingston, NY, pp 131-135.

Barbara, J. and Malgorzata, W. (2006). The metal uptake and accumulation in fish living in polluted waters. Soil and Water Pollution Monitoring Protection and Remediation, 69: 107-114.

Cerqueira, C. and Fernandes, M. (2002). Gill tissue recovery after copper exposure and blood parameter responses in the tropical fish Prochilodus scrofa. Ecotoxicology and Environmental Safety, (52): 83-91.

Chomczynski, P. and Sacchi, N. (1987). Single-step method of RNA isolation by acid guanidinium thiocyanate-phenolchloroform extraction. Anal Bioch-emistery, 162: $156-159$.

Chrysomali, E.; Nikitakis, N. G.; Tosios, K.; Sauk, J. J. and Papanicolaou, S. I. (2003). Immunohistochemical evaluation of cell proliferation antigen Ki-67 and apoptosisrelated proteins Bcl-2 and caspase-3 in oral granular cell tumor. Oral Surg. Oral Med. Oral Pathol. Oral Radiol. Endod., 96(5): 566-572.

EL-Naggar, A.M; Mahmoud, S.A. and Tayel, S.I. (2009). Bioaccumulation of some heavy metals and histopathological alterations in liver of Oreochromis niloticus in relation to water quality at different localities along the river Nile, Egypt. World J. Fish and Marine Science, 1(2):105-114.

El-Naggar, A.M.; Richard A.H.; Mohamoud, S.A. (2011). A survey and history of Helminth fish parasites from the Nile River. Egypt. Proceedings of Parasitology, 51: $59-85$.

El-Serafy S.S.; El-Haweet A.A.; El-Ganiny A.A. and El-Far A.M. (2014). Qarun Lake fisheries; Fishing gears, Species composition and Catch per unit effort. Egypt. J. Aquat. Biol. \& Fish., 18 (2): 39- 49.

Figueiredo-Fernandes, A.; Ferreira-Cardoso, J. V.; Garcia-Santos, S.; Monteiro, S.M.; Carrola, J. and Matos, P. (2007). Histopathological changes in liver and gill epithelium of Nile tilapia, Oreochromis niloticus, exposed to waterborne copper. Pesq. Vet. Bras., 27(3):103-109.

Froese, R.; Winker, H.; Gascuel, D.; Sumaila, U. and Pauly, D. (2016). Minimizing the impact of fishing. Fish and fisheries, (17):785-802.

Hsu, S.M.; Raine, L. and Fanger, H. (1981). Avidin and biotin in immunohistochemistry. Histochemistery. Cytochemistery, (29): 1349-1353.

Mageed, A.A. (1998). Distribution and salinity ranges of zooplankton organisms at ElFayoum Depression (El-Fayoum-EGYPT). Egypt J. Aquat BioL \& Fish, 2 (2) : $51-71$.

Mallatt, J. (1985). Fish gill structural changes induced by toxicants and other irritants: a statistical review. Can. J. Fishery Aquatic Science. (42):630-648.

Mancera, J.M. and Mcormick, S.D. (2007). Role of prolactin, growth hormone, insulinlike growth factor I and cortisol in teleost osmoregulation. Fish Osmoregulation, Science Publishers, Enfield, NH. 497-515.

Neuraste, N.; Setorki, M.; Tehranifard, A. and Moshfegh, A. (2017). Effects of salinity and plasma prolactin on chloride cells in the gill of Chalcalburnus chalcoides. Iranian Journal of Aquatic Animal Health, 3(2) 11-21.

Paris-Palacios, S.; Biagianti-Risbourg, S. and Vernet, G. (2000). Biochemical and (ultra)structural hepatic perturbation of Brachydanio rerio (Teleostei, Cyprinidae) exposed to two sublethal concentrations of copper sulphate. Aquatic Toxicology, 50:109-124.

Payne, A. T. (1986). The ecology of tropical lakes and rivers. John Wiely \& Sons. Chichester, New york. Tornto, Brisbane and Singapore 300 pp. 
Riche, M. and Williams, T. (2010). Apparent digestible protein, energy, and amino acid availability of three plant proteins in Florida pompano, Trachinotus carolinus $L$. in seawater and low salinity water. Aquacult. Nutr., 16: 223-230.

Sakamoto, T. and McCormick S.D. (2006). Prolactin and growth hormone in fish osmoregulation. Gen. Comp. Endocrinol., (147):24-30.

Salinas, I.; Zhang, Y. and Sunyer, O. (2011). Mucosal immunoglobulins and B cells of the teleost fish. Developmental and Comparative Immunology. 35: 1346-1365.

Sandra, O.; Sohm, F.; de Luze, A.; Prunet, P.; Edery, M. and Kelly P. (1995). Expression cloning of a cDNA encoding a fish prolactin receptor. Proc Natl Academic Science USA, 92:6037-6041.

Sharma, B.; Singh, S. and Siddiqi, N. (2014). Biomedical implications of heavy metals induced imbalances in redox systems. Bio. Med. Res. Int., 26-28.

Suresh, A. V. and Lin, C. K. (1992). Tilapia culture in saline water: a review. Aquaculture, (106): 3, 43-44, 201-226.

Suvarna, K.; Layton, C. and Bancroft, J. D. (2018). Bancroft's Theory and Practice of Histological Techniques, 8th Edition, London, Elsevier; 672.

Tang, Y.; Shepherd, B.S.; Nichols, A.J.; Dunham, R.; Thomas, T. and Chen, T.T. (2001). Influence of Environmental Salinity on Messenger RNA Levels of Growth Hormone, Prolactin, and Somatolactin in Pituitary of the Channel Catfish (Ictalurus punctatus). Biotechnol., 3: 205-217.

Van Heerden, D.; Vosloo, A. and Nikinmaa, M. (2004). Effects of short-term copper exposure on gill structure, methallothionein and hypoxia-inducible factor-1á (HIF1á) levels in rainbow trout (Oncorhynchus mykiss). Aquatic Toxicology, 69: 271280.

Woo, N.Y.S.; Ng, T.B.; Leung, T.C. and Chow, C.Y. (1997). Enhancement of growth of tilapia, Oreochromis niloticus in iso-osmotic medium. Journal of Applied Ichthyology, 13(2): 67-71.

Yada, T.; Kobayashi, T.; Urano, A. and Hirano, T. (1992). Changes in growth hormone and prolactin messenger ribonucleic acid levels during seawater adaptation of amago salmon (Oncorhynchus rhodurus). Journal Exp Zoology, 262 :420-425.

Yada, T.; Uchida, K.; Kajimura, S.; Azuma, T.; Hirano, T. and Grau, E. (2002). Immunomodulatory effects of prolactin and growth hormone in the tilapia, Oreochromis mossambicus. Journal of Endocrinology, 173: 483-492.

Yamaguchi, Y.; Breves, j.; Haws, M.; Lerner, D.; Grau, E. and Seale, A. (2018). Acute salinity tolerance and the control of two prolactins and their receptors in the Nile tilapia (Oreochromis niloticus) and Mozambique tilapia (O. mossambicus): A comparative study. Gen Comp Endocrinol., (1)257:168-176.

Yoon, G., Al-Saadi, N. and Ambuali, A. (2015). Gill histology of Nile tilapia Oreochromis niloticus following chronic and acute exposure to ammonia. Journal of Agricultural and Marine Sciences, 19 (1): 66-72.

Yuan, X.; Yang, H.; Wang, L.; Zhou, Y. and Gabr H. (2010). Effects of salinity on energy budget in pond-cultured sea cucumber Apostichopus japonicus (Selenka) (Echinodermata: Holothuroidea). Aquaculture J., 306(2): 348-351.

12-Wadi El-Rayan Protected Area in Fayoum Governorate. Ministry of Environment Environmental Affairs Protectorate. Ministry of Environment Egypt. Retrieved 23 May2018.

http://www.eeaa.gov.eg/enus/topics/nature/protectorates/protectoratesdescrip tion.aspx. 


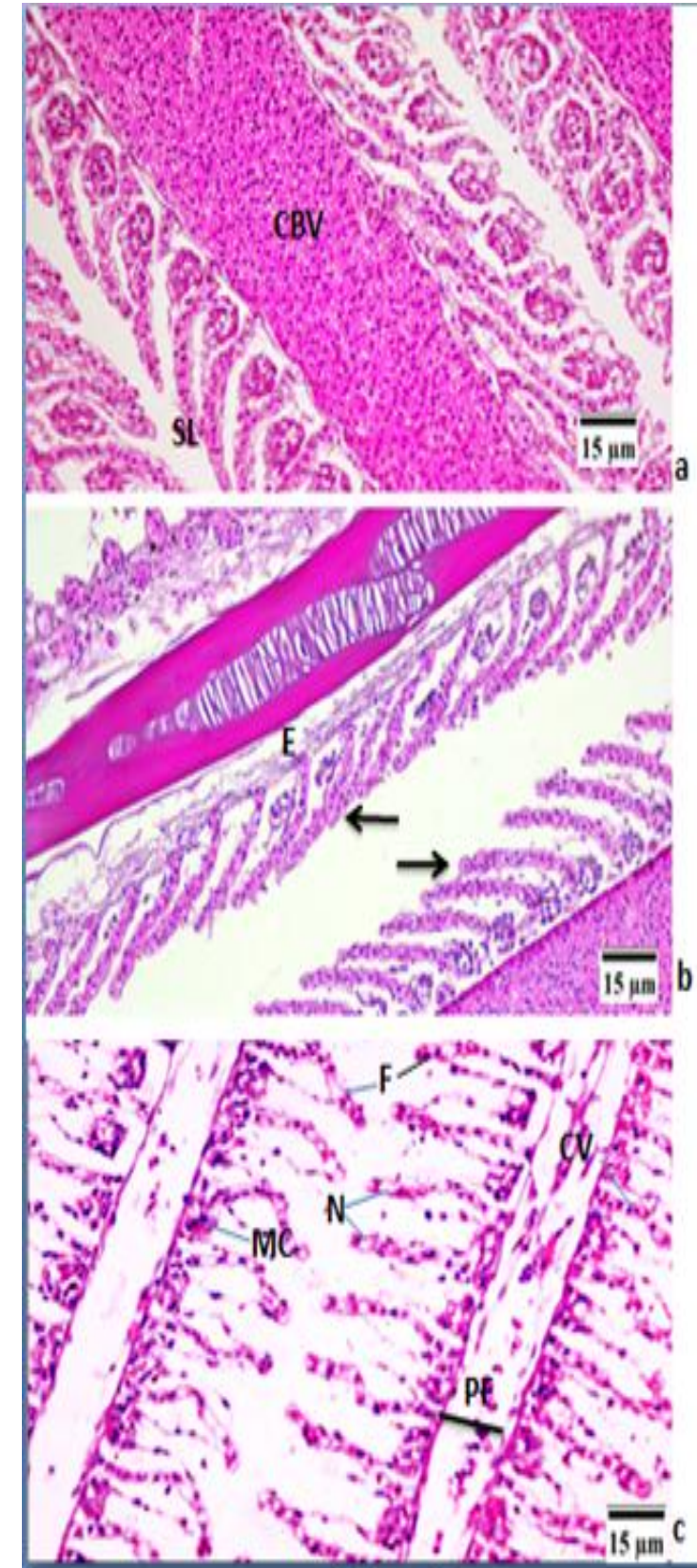

Figure 2
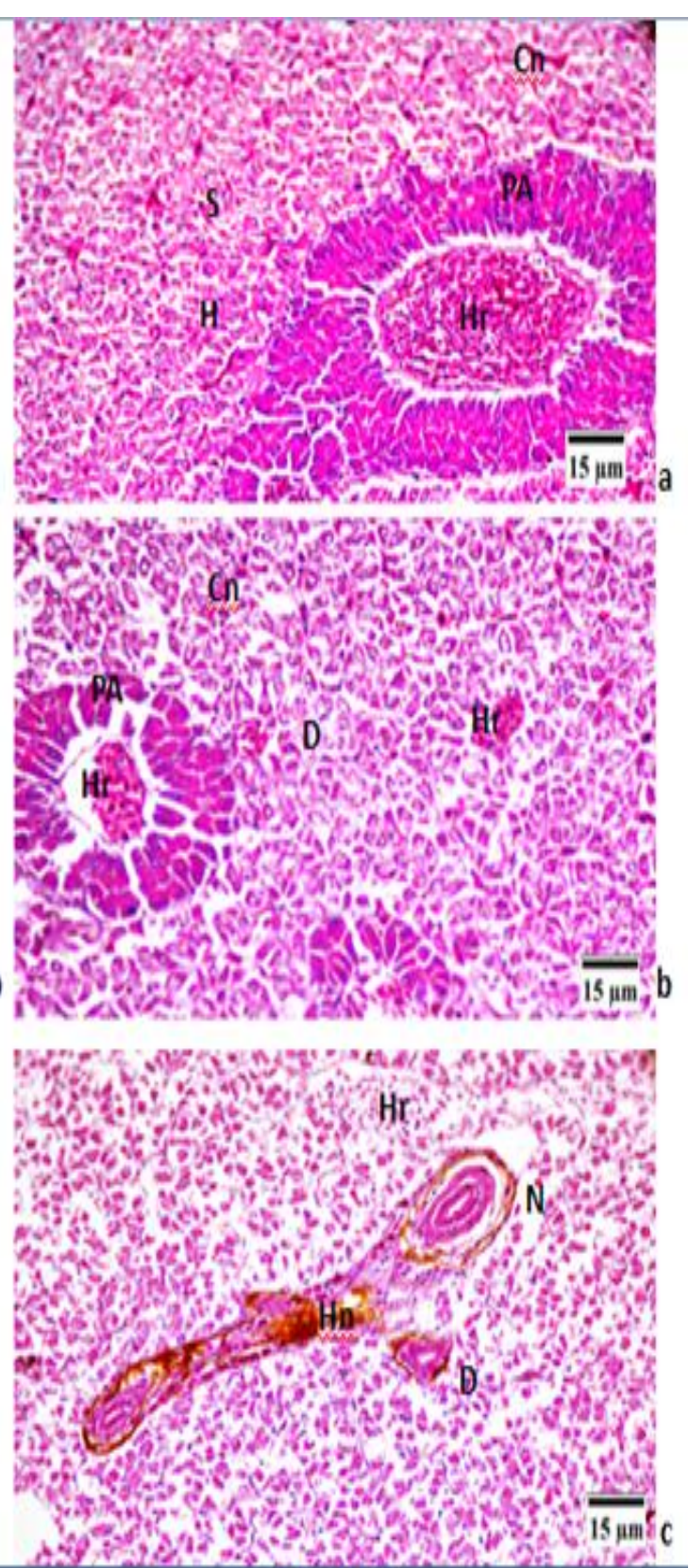

Figure 3

Fig. 2: Gill sections of C. zillii obtained from (a) WR1, (b) WR2, and (c) Qaroun lake showing secondary lamellae (SL), congested blood vessel (CBV), lifting of the lamellar epithelium (arrows), edema (E), primary filament (PF), fusion of the secondary lamellae (F),cytoplasmic vacuolation $(\mathrm{CV})$ necrosis $(\mathrm{N})$, mucus cells $(\mathrm{MC})$, Scale bars correspond $=15 \mu \mathrm{m}, \mathrm{H} \& \mathrm{E} . \times$ 400 .

Fig. 3 : Liver sections of C. zillii obtained from (a) WR1, (b) WR2, and (c) Qaroun lake showing hepatocytes $(\mathrm{H})$, blood sinusoid $(\mathrm{S})$, pancreatic area $(\mathrm{Pa})$, congestion $(\mathrm{Cn})$ in blood sinusoids, degeneration (D), necrosis $(\mathrm{N})$, edema $(\mathrm{E})$, hemorrhage $(\mathrm{Hr})$ in both hepatic and pancreatic area, Hemosidrin $(\mathrm{Hn})$, Scale bars correspond $=15 \mu \mathrm{m}, \mathrm{H} \& \mathrm{E} . \times 400$. 


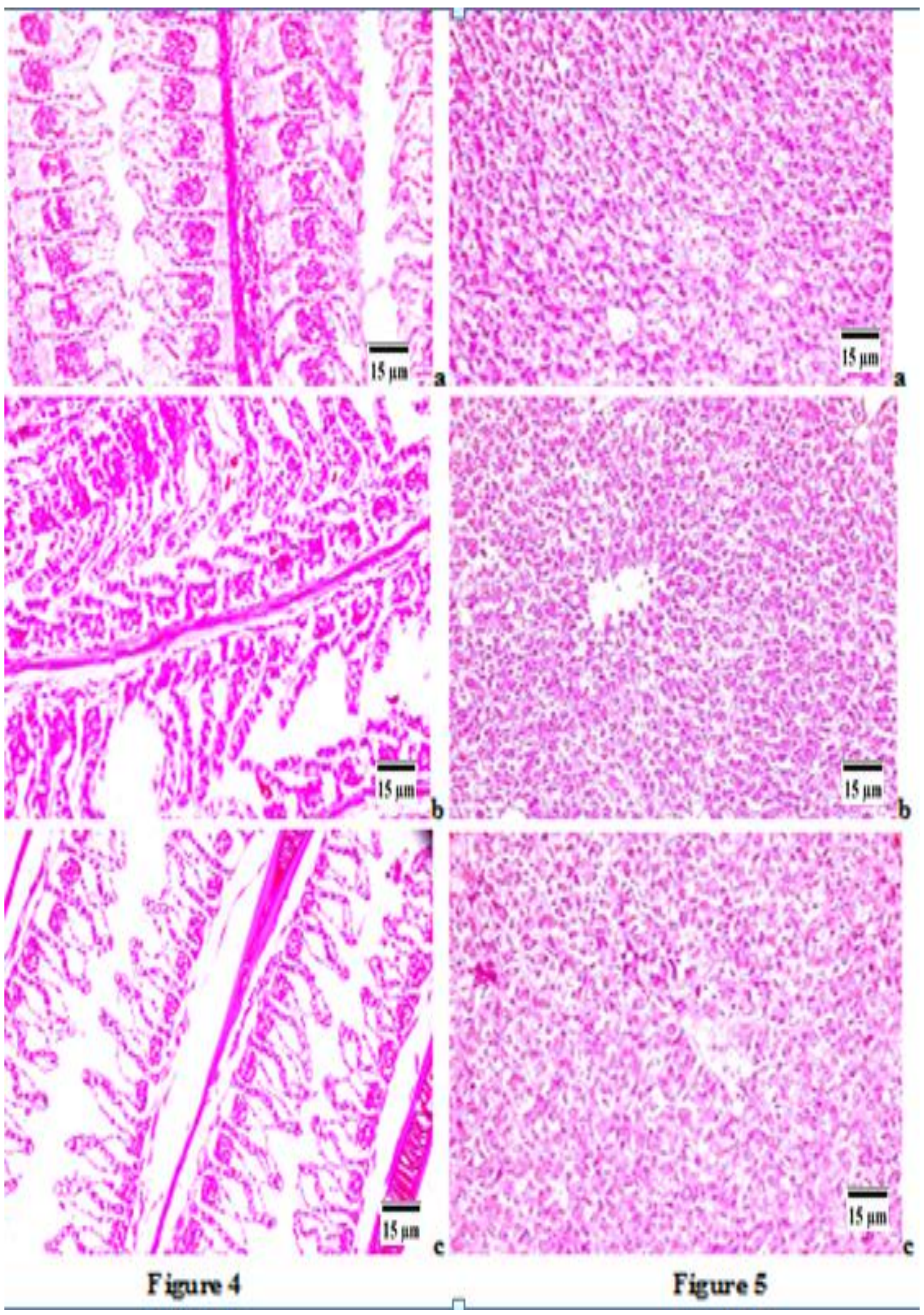

Figs. 4 \& 5: Gills and liver sections of $C$. zillii obtained from (a) WR1, (b) WR2, and (c) Qaroun lake showing the distribution of carbohydrates in cells cytoplasm, Scale bars correspond = $15 \mu \mathrm{m}$, Periodic acid Schiff's $\times 400$. 

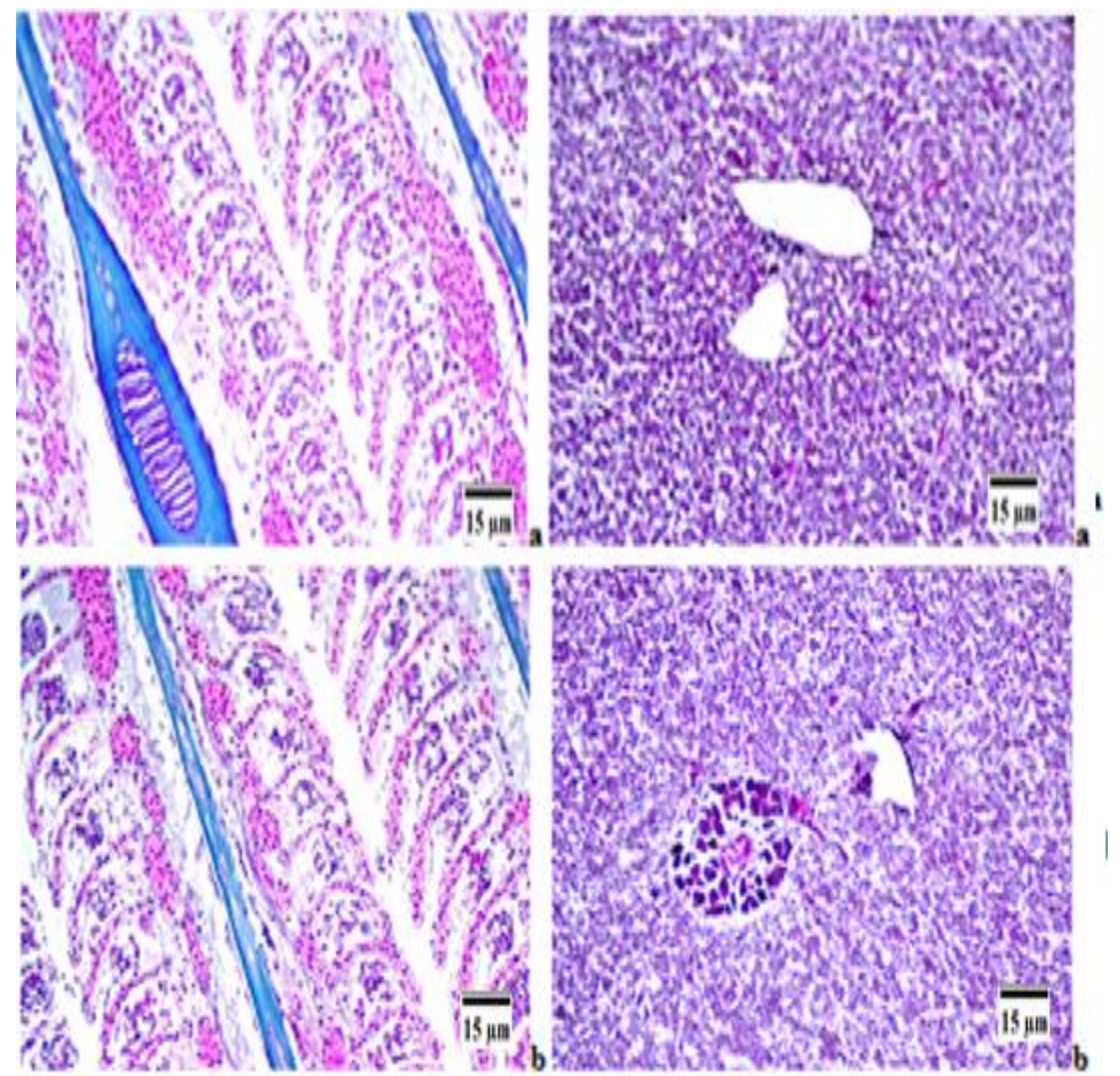

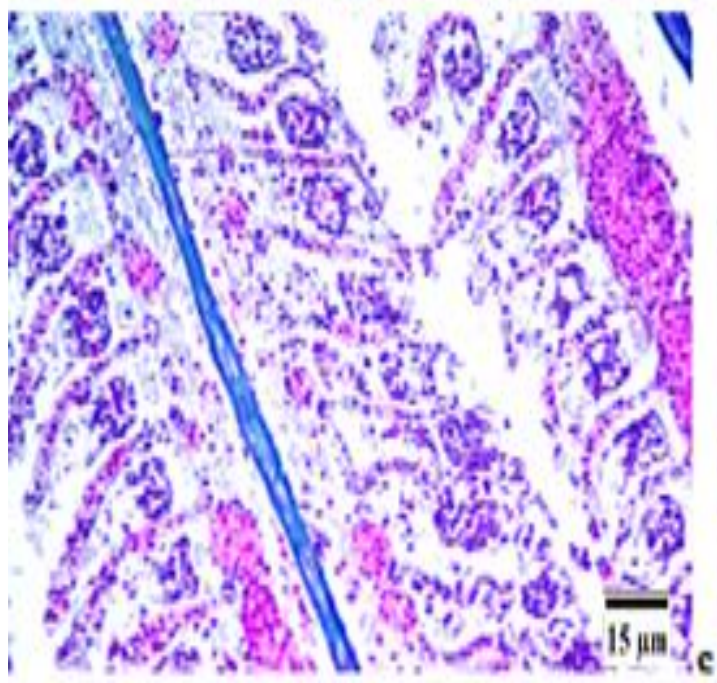

Figure6

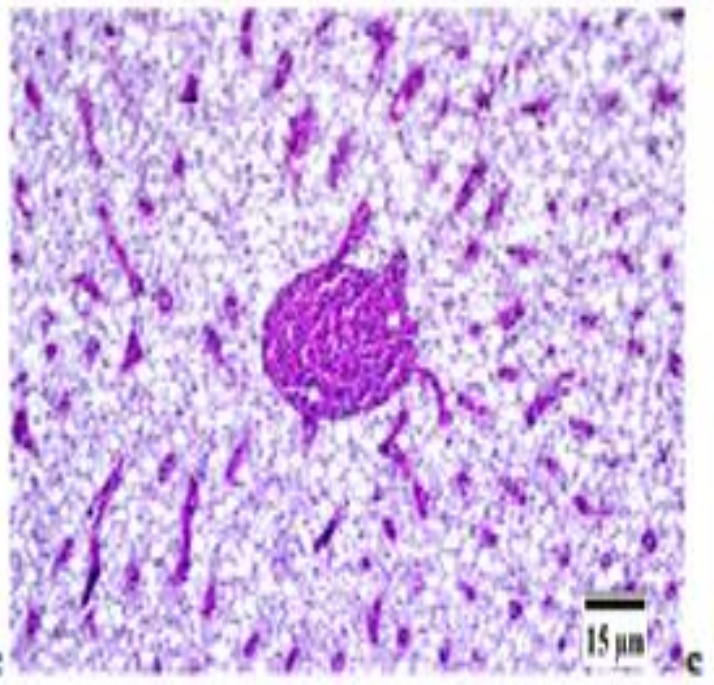

Figure7

Figs. 6\&7: Gills and liver sections of $C$. zillii obtained from (a) WR1, (b) WR2, and (c) Qaroun lake showing distribution of collagen fibers, Scale bars correspond $=15 \mu \mathrm{m}$, Masson's Trichrome $\times 400$. 


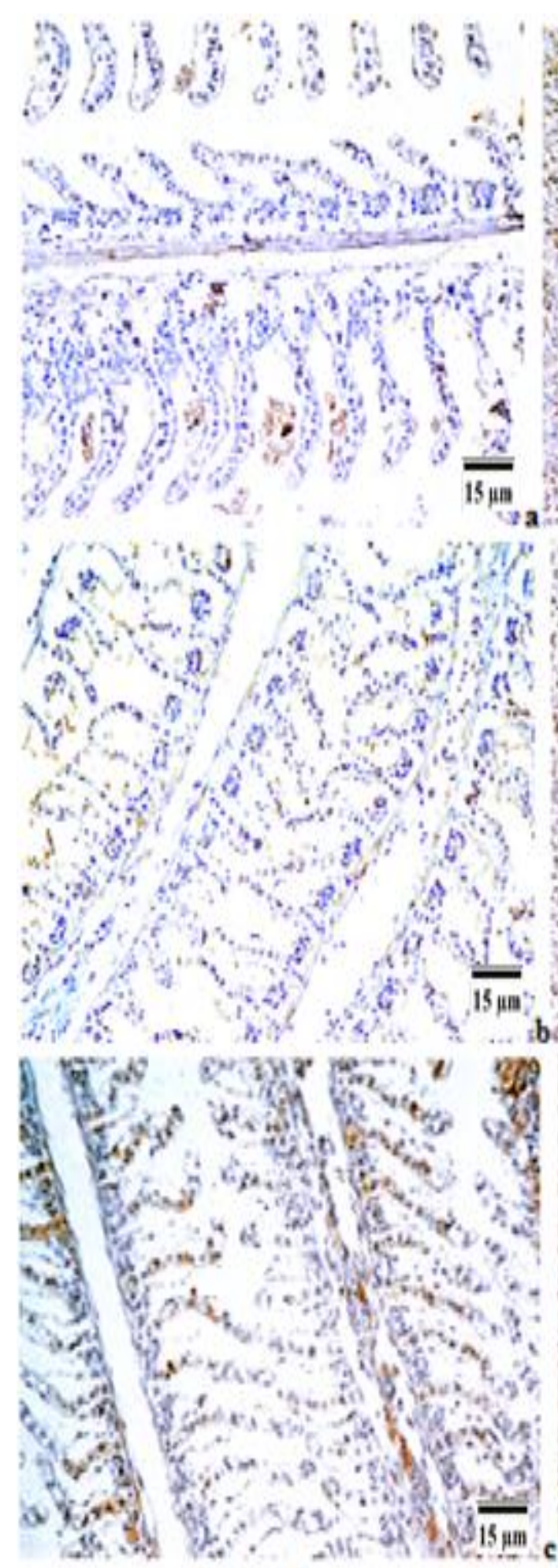

Figure 8

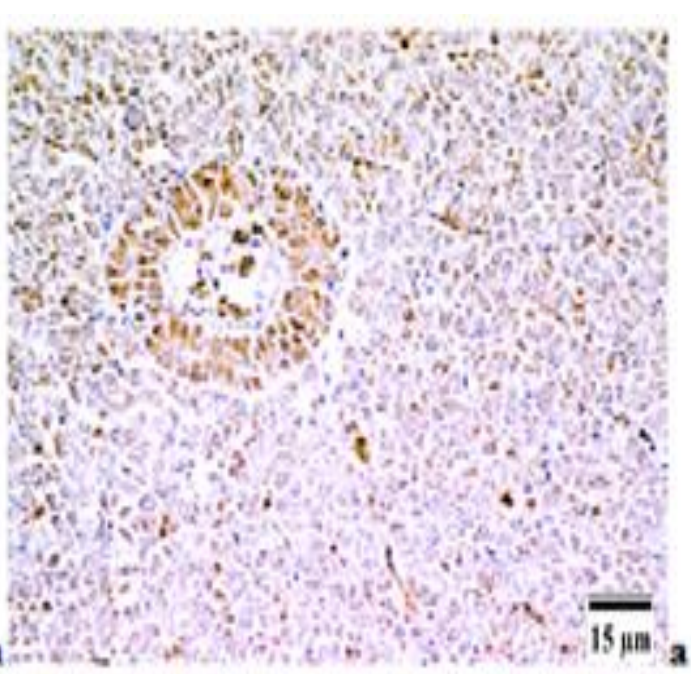

is a

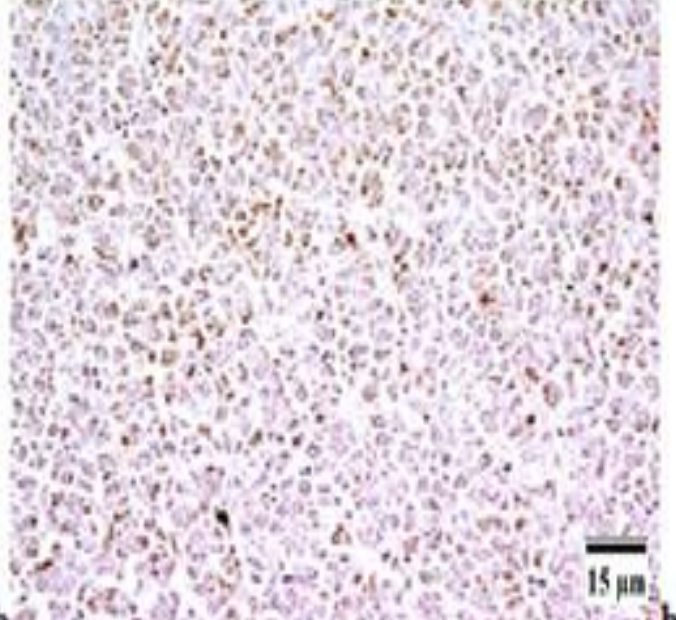

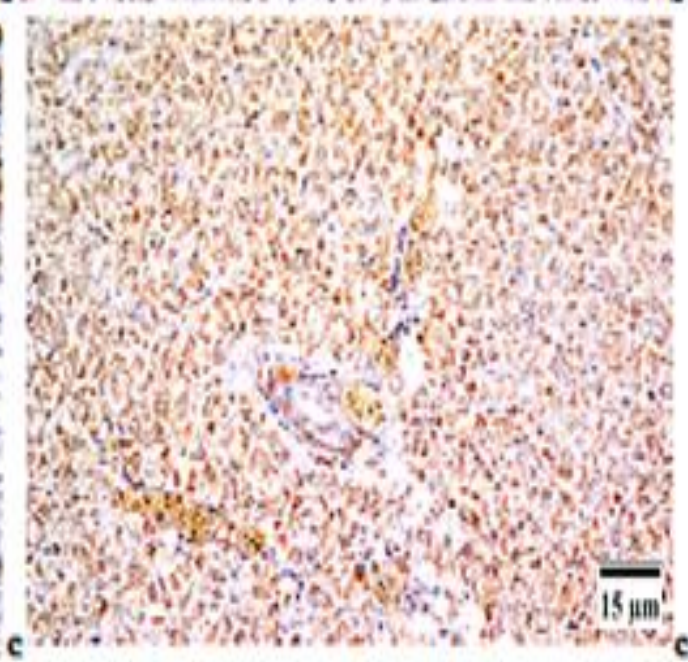

Figure 9

Figs. 8 \& 9: Gills and liver sections of $C$. zillii obtained from ((a) WR1 (b) WR2 and (c) Qaroun lake showing expression of caspase- 3 as brownish color in cells cytoplasm, Scale bars correspond $=15 \mu \mathrm{m}, \mathrm{IHC} \times 400$. 


\section{ARABIC SUMMARY}

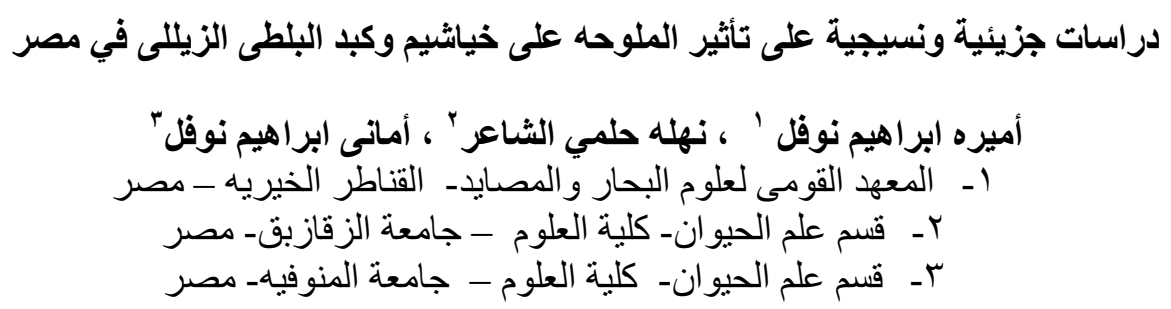

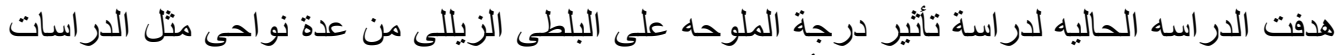

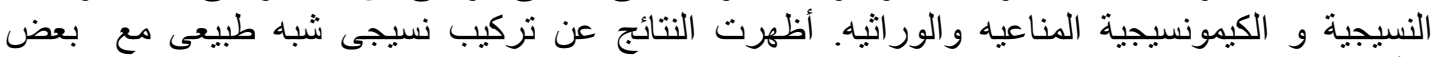

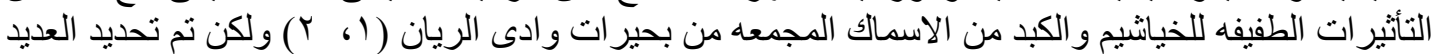

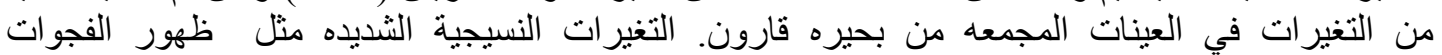

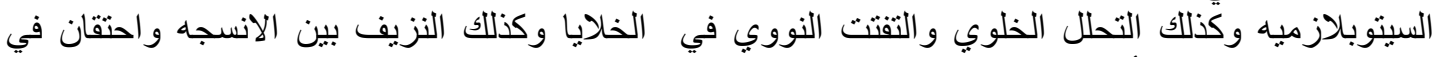

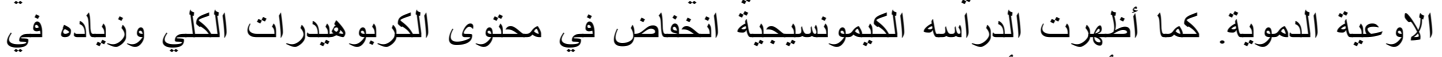

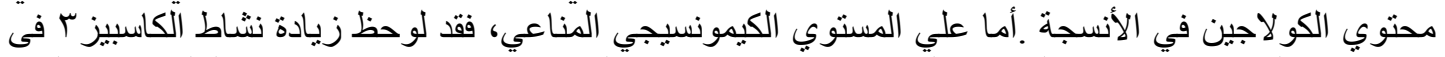

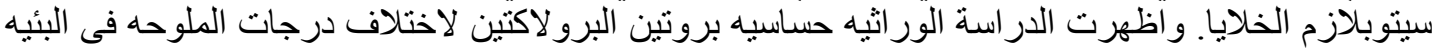
الخارجيه و انه يلعب دور هام جدا فى قدرة اسماك البلطى على التكيف للمعيثه في بيئات متعددة الملوحهـ. 